\title{
Problem-Solving in the Trickster Tales of Nasrdin Avanti: Folktales from the Uyghur People
}

\author{
Intira Charuchinda (อินทิราจารุจินดา) \\ Assistant Professor, English Department, Faculty of Humanities and \\ Social Sciences, Phranakhon Rajabhat University, Thailand \\ limsongprot@gmail.com
}

\begin{abstract}
Trickster tales can be found in the folklore of various preliterate people. Nasrdin Avanti is a series of humorous trickster tales from the Uyghur people. In this series, the protagonist Nasrdin Avanti confronts a variety of problems or difficulties, but is able to overcome or solve them. This paper explores Nasrdin Avanti's problem-solving strategies as found in the book, The Frog Rider: Folk Tales from China, which contains 29 of his stories. Moreover, this paper discusses the functions of these folktales in their cultural and social contexts. It finds that the trickster hero uses eight strategies, the most frequent of which is talking nonsense (six stories), while the others include: feigning ignorance (four stories), satirizing (four stories), using the same reasons as the antagonists (four stories), playing on words (three stories), staying one jump ahead (three stories), taking advantage of the situation (three stories), and flattering (two stories). These problem-solving strategies can cause antagonists to lose face, stop people from bothering the trickster hero or prevent them from taking advantage of him, provide other people with new perspectives, and make them happy. In addition, the folktales of Nasrdin Avanti fulfil different social and emotional functions. Paradoxically, they provide amusement and allow people to escape from the harsh realities in their everyday lives, while at the same time, helping to retain social values and inculcate moral lessons.
\end{abstract}

\section{Keywords}

Nasrdin Avanti - problem-solving - trickster tale - folktale - Uyghur

(C) INTIRA CHARUCHINDA, 2019 | DOI:10.1163/26659077-02202002

This is an open access article distributed under the terms of the prevailing CC-BY-NC License at the time of publication. 


\author{
บทคัดย่อ \\ การแก้ปัญหาในชุดนิทานตลกเจ้าปัญญานาสรูดิน อะวานติ: นิทานพื้นบ้านของชาวอุยกู
}

นิทานตลกเจ้าปัญญามีในคติชนของสังคมหลายแห่งที่ยังไม่มีภาษาเขียน เรื่องราวของนาสรูดิน อะวานติเป็นชุดนิทานตลกเจ้า ปัญญาของชาวอุยกูร์ ในนิทานชุดนี้มีตัวละครเอกชื่อนาสรูดิน อะวานติ เขาประสบปัญหาหรือสถานการณ์ยุ่งยากต่างๆ แต่เขา จัดการแก้ปัญหาและสถานการณ์เหล่านี้ได้ บทความนี้มุ่งศึกษากลวิธีการแก้ปัญหาของนาสรูดิน ที่ปรากฏในหนังสือเดอะ ฟ รอกไรเดอร์ ซึ่งประกอบด้วยนิทานตลกเจ้าปัญญานาสรูดิน อะวานติ จำนวน 29 เรื่อง และบทความนี้อภิปรายบทบาทหน้าที่ ของนิทานพื้นเมืองดังกล่าว ผลการศึกษาพบว่า นาสรูดินใช้กลวิธีการแก้ปัญหา 8 กลวิธี โดยเรียงลำดับจากมากไปน้อย ดังนี้ 1. พูดเหลวไหล $(6$ เรื่อง $) 2$. แสร้งไม่รู้ $(4$ เรื่อง $) 3$. ประชดประชัน $(4$ เรื่อง $)$ 4. หนามยอกเอาหนามบ่ง $(4$ เรื่อง $) 5$. เล่นคำ เล่นความ ( 3 เรื่อง $) 6$. ดักทาง $(3$ เรื่อง $) 7$. พลิกสถานการณ์ ( 3 เรื่อง) และ 8 . ป้อยอ $(2$ เรื่อง $)$ กลวิธีเหล่านี้อาจทำให้ตัว ละครคู่ตรงข้ามเสียหน้า ยับยั้งการก่อกวนหรือการเอาเปรียบ ทำให้ตัวละครคู่ตรงข้ามมีมุมมองใหม่ และทำให้ผู้อื่นมีความสุข นอกจากนี้ยังพบว่านิทานพื้นบ้านชุดนี้มีบทบาทหน้าที่อันย้อนแย้งทางสังคมและทางอารมณ์ กล่าวคือ นิทานตลกเจ้าปัญญาชุด นี้ นอกจากจะทำให้ผู้ฟังได้รับความเพลิดเพลินแล้ว ก็ช่วยให้ผู้ฟังปลดปล่อยตนเองจากความจริงอันโหดร้ายที่ต้องเผชิญในชีวิต ประจำวัน และอีกทางหนึ่งนิทานชุดนี้ช่วยธำรงค่านิยมสังคมและสอนคติธรรม

\title{
Introduction
}

Folklore is considered to be an accumulation of oral wisdom and the verbal arts, handed down from one generation to another. One of the most studied forms of folklore is that of reading folktales. Thompson (1949: 408-409) notes that there is no known culture in the world without the folktale. He also writes that the term 'folktale' in a broad sense refers to all forms of prose narrative, written or oral, which have come to be transmitted through the years (1977: 2). However, the folk narrative as unwritten literature is free to change and to lose motifs which do not fit a new environment (Clarke and Clarke 1963: 39). This opens up a discussion about the meaning of folktales in relation to their cultural and social contexts.

Nonetheless, the study of folklore remains incomplete without interpretation. Gramsci (1971: 35) points out the importance of folklore. For Gramsci, culture is actively appropriated to serve the state. Countering the nationalistic and elitist canons, he refuses to see folklore as merely residual, recognizing how folklore could compete with hegemonic culture and suggesting that it should be taken seriously. In a similar way, Dundes (1965) proposes that the identification of folklore in literature should be a step towards interpretation. His new critical agenda counters the hegemonic perception that folklore can be considered only a relic of the past. For him, folklore literature should be accorded a place in the process of literary interpretation. These ideas have led to interpreting the functions of folklore. 
One approach to folklore interpretation is to study how folklore functions in its cultural and social contexts. Bascom (1954:343) proposes that functionalism is important in folklore studies in relation to its culture. The first function is entertainment. For Bascom, folklore's entertaining qualities are a remarkable element of its value. He also suggests that in invoking play and humor, people use folklore to express deeper meanings. In his view, amusement allows people to find relief from the repressions imposed by society. He points out that folklore provides a safe place to express difficult subjects with humor and playfulness. This outlet for repression, anxiety and fantasy provides a release, so that people in society can find relief from frustration and acceptance of the prevailing order. Secondly, folklore validates cultural activities and thirdly teaches social values, so that cultural continuities can be built across generations. Lastly, folklore maintains conformity to dominant patterns of behavior. Bascom (1954: 349) concludes that while folklore provides a person with a compensatory escape from the harsh realities of - among others-inequality and injustice in daily life, at the same time it provides socially approved alleviation of repression imposed by the same institution. Thus, the functions of folklore are paradoxical. Moreover, folklore, as Bronner (2017) contends, deals with insufficiencies of scientific knowledge and the understanding of physiological experience. This provides a sense of control over nature and of the experience of the human body. In addition, McNeill (2013: 31) writes that the same item of folklore can serve multiply. As cultural expressions, folktales function valuably in society as do other types of folklore. In this light, the folktale is a subject of serious study in terms of its functions.

Among various types of narrative folklore, the trickster tale is especially popular. Trickster tales are a variety of humorous stories loved by a wide audience. According to Merriam-Webster's Encyclopedia of Literature (1995: 1130-1131), oral traditions worldwide provide tales of deceit, magic and violence perpetrated by tricksters. In these tales, the trickster hero may be regarded within a given society as a creator god or as an innocent fool, an evil destroyer or a childlike prankster. Trickster tales present picaresque adventures in which the trickster hero encounters a situation and responds to it admirably or stupidly. Usually, the trickster hero is accompanied by an animal companion who serves either as a stooge or itself tricks the trickster. According to Hansen (2001: 28), tricksters are of a character type found in mythology, folklore, and literature worldwide, appearing as animals, humans and gods. They have several common traits and one of their most significant qualities is nonconformity to the establishment. Typically—almost uniquely—they are male. They often use their tricks to confront and counter larger and more powerful beings. They may be both cultural heroes and selfish buffoons. 
Many countries and cultures have their own unique tricksters, and there is considerable diversity among them. As Merriam-Webster's Encyclopedia of Literature (1995: 1130-1131) writes, the existence of trickster figures appears to be a universal characteristic. For example, Fox Kitsune is the renowned trickster of Japanese literature, and in Buddhist stories the fox is also cast as an evil entity capable of possession. Scandinavian mythology narrates the deeds of the trickster Loki, portrayed as a resourceful being associated with the god Thor in Thor's Hammer. As for Thai literature, Srithanonchai is a famous trickster who outwits other characters, including the king. Apart from these trickster tales, the series of folktales about Nasrdin Avanti is particularly well-known in the Middle East, where it has gained worldwide popularity and become timeless.

The stories of Nasrdin Avanti have been told in many regions, and the trickster hero (here referred to as Nasrdin Avanti) has many names in the different cultures he is featured in. Among the Uyghur ethnic minority, he is known as Nasrdin Avanti. According to Shelton (2014:1), Egyptians know him as the prankster Goha, and among the Chinese, he is the wise Affanti. Also, he has other names. Alexander (2003: 5) writes that in Sephardic communities, he is known as Joha, and in medieval Turkish folktales there is a similar character named Nar-a-din Hodja. Moreover, in modern Turkish he is called Nasreddin. Furthermore, we find a similar character named Mulla Nasreddin or Nasrudin Hoja in the folktale collection of Elcot (2003), where his history is shown to be variable.

Elcot (2003) writes that "Mulla Nasreddin or Nasrudin Hoja" [sic] was a legendary folk hero of medieval times, presumed to have come from Turkestan in Central Asia, and thus quite at home in the Persian and Afghan cultures. Attributed to the thirteenth century, the trickster hero has been claimed by several nations of the Near and Middle East and Central Asia as theirs. That the story of Nasrdin Avanti has gone so far as Turkey is evidenced by his grave there and an annual Nasrdin Festival. During this lifetime, he was a commoner with an average education, living in a rural town. He was a farmer, trader, lawyer, minor judge, physician, or an occasional visitor to the royal court. Another claim about his origin is offered by Shelton (2014: 1), who says Nasrdin Avanti was born in 1208 in Horto village near Sivrihisar in the Turkish heartland of Central Anatolia, the son of an imam. As an adult, he may have served as a judge, an imam, a teacher, and a dervish, and is said to have died in 1284 in Askshehir. Another claim for this trickster hero is made by Mikail Bayram, ${ }^{1}$ who conducted in-depth research on Nasrdin and wrote that Nasrdin was born

1 From Wikipedia. Retrieved October 13, 2017. 
in Khoy, Iran, and educated in Khorasan, serving as a judge in Kayseri and living in many cities over a vast area.

As mentioned previously, a group claiming Nasrdin as their own is the Uyghur people. ${ }^{2}$ The Uyghurs are an Islamic community, today living in the Xinjiang Uyghur Autonomous Region in the west of the People's Republic of China, officially recognized as one of the country's 55 ethnic minorities, and considered to be genetically related to both European and East Asian populations. The Uyghurs are a physically diverse ethnic group, in appearance ranging from Caucasian to Mongoloid. The history of the Uyghur people, as with their ethnic origin, is a matter of contention between Uyghur nationalists and the Chinese authority. According to Bovingdon (2010), in 1759, the vast territory of what is today China's north-western region of Xinjiang was conquered by China and incorporated into the empire. However, a large number of Uyghurs have resisted this incorporation, Uyghurs of a Muslim minority in North-western China having sought greater autonomy or independence. They believe themselves to be part of a distinct Uyghur nation, with its own rightful homeland, history, culture, and language. However, the Chinese government refuses to accept this claim, emphasizing as it does interethnic harmony and Chinese nationalism. China's leaders continue to refuse to recognize the differences of physiology, habitus, religion, and socioeconomic status that distinguish the Uyghurs from the ethno-national Han majority, whose members comprise more than ninetenths of China's population. Thus, a study of Uyghur folklore promises to open doors to the world and disclose more about this minority group that has attempted to achieve independence in conformity to their own identity.

The folktales of Nasrdin Avanti are elements of the folklore of the Uyghur people. These stories are entertaining and amusing not only for the Uyghur people in relation to their culture, but for wider audiences. They reflect the social rules and regulations of a Muslim society where open criticism of social beliefs and conditions is strongly discouraged, but in the realm of such tales, the characters are allowed to tease, ridicule, and even make jokes about the ruling class and religious leaders in a more consistent and direct way than would elsewhere have been possible. These stories deal with the fundamentals of human nature, featuring aspects of social injustice, the privileges of the upper class, selfishness among the common people, and individual incompetence, greed, ignorance, and stinginess of all kinds, to mention only a few of

2 From Wikipedia. Retrieved June 7, 2016. 
these aspects. As the trickster hero of these stories, in his picaresque adventures, Nasrdin Avanti is accompanied by a donkey, on which he often rides backward, encountering numerous problems, which his wittiness, cleverness, and resourcefulness enable him to solve.

Confronted by the trickster hero in these folktales, the problems can sometimes be attributed to the conflicts arising from disparities between the trickster hero's perspectives and those of his antagonists. Whereas some antagonists exercise their privileges to the extent of abusing others, in his disapproval of such behaviour, Nasrdin Avanti wittingly subverts them. And where some antagonists break social regulations, or shrink from their duties, he thwarts their schemes, or makes them perform their roles, requiring them to do what is expected of them. In some stories, the trickster hero, showing solidarity with people of low standing, struggles against the king, religious leaders, and rich people, representing the elites as determined to maintain their privileges. In other stories, the trickster hero acts within the dominant patterns of the social hierarchy, requiring people to know their positions and perform their roles there. Furthermore, in pursuit of his ends, the trickster hero uses his tricks to make his opponents aware of their duties, sometimes to the extent of causing them to act from shame. All this is in accordance with the conflict theory, where the major patterns of inequality in society promote social stability in some circumstances and social change in others (Brym and Lie 2005: 14).

Objectives

The primary objective of this paper is to find out how Nasrdin Avanti solves the various problems with which he is confronted. The secondary objective is to discuss the functions of these folktales in their cultural and social contexts.

\section{3}

Scope of the Study

As aforementioned, the folktale is a story passed down by word of mouth rather than in writing, and thus is partly modified by successive retelling before being written down or recorded. Noteworthy is the fact that the stories of Nasrdin Avanti are embraced by various cultures, as also is the fact that the writer of this series of stories and its origins are unknown. However, the discussion of this paper is limited to the version compiled and translated into English by Zhang Suchu (1980) and is part of the book The Frog Rider: Folk Tales from 
China. This series features the stories of the Nasrdin Avanti who has been embraced by the Uyghur culture, twenty-nine of them in all.

\section{$4 \quad$ Findings}

The antagonists who play tricks, cause problems, make jokes, or ask questions in this series of folktales, include the king, thieves, shopkeepers, animals, the trickster hero's wife, his friends, and people in general. In dealing with them, TABLE 1 Problem-Solving Strategies

\begin{tabular}{|c|c|c|c|c|}
\hline & $\begin{array}{l}\text { Problem- } \\
\text { Solving Strategy }\end{array}$ & $\begin{array}{l}\text { Frequency } \\
\text { (stories) }\end{array}$ & Percentage & Stories \\
\hline 1. & Talking nonsense & 6 & 20.6 & $\begin{array}{l}\text { (1) I'm Wrong, (2) Ask the Cow } \\
\text { Herself, (3) Fish Will Climb a } \\
\text { Tree, (4) All Directions, (5) The } \\
\text { Moon, (6) The Sun or the Moon }\end{array}$ \\
\hline 2. & Feigning ignorance & 4 & 13.8 & $\begin{array}{l}\text { (1) The Thirsty Pouch, }(2) \\
\text { Selling a Cow, (3) His Tail in the } \\
\text { Bag, (4) Expiation }\end{array}$ \\
\hline 3 . & Satirizing & 4 & 13.8 & $\begin{array}{l}\text { (1) Hiding from the Thief, } \\
\text { (2) At the Barber's, (3) The } \\
\text { Guest and the Honey (4) Jump } \\
\text { into the Water! }\end{array}$ \\
\hline 4. & $\begin{array}{l}\text { Using the same } \\
\text { reasons as the } \\
\text { antagonists }\end{array}$ & 4 & 13.8 & $\begin{array}{l}\text { (1) The Only Remedy, (2) The } \\
\text { Ring, (3) The Price of a Fowl, } \\
\text { (4) Difficult Questions }\end{array}$ \\
\hline 5 . & Playing on words & 3 & 10.3 & $\begin{array}{l}\text { (1) A Bargain Made Even, } \\
\text { (2) The Baggage of Two Asses, } \\
\text { (3) Good Advice }\end{array}$ \\
\hline 6. & $\begin{array}{l}\text { Staying one jump } \\
\text { ahead }\end{array}$ & 3 & 10.3 & $\begin{array}{l}\text { (1) It's No Good to Be Inside, } \\
\text { (2), Write for Me (3) Path Along } \\
\text { the Tree-tops }\end{array}$ \\
\hline 7. & $\begin{array}{l}\text { Taking advantage } \\
\text { of the situation }\end{array}$ & 3 & 10.3 & $\begin{array}{l}\text { (1) Avanti Moves House, (2) } \\
\text { What Does the Owl Say? (3) The } \\
\text { Pot Bears a Son }\end{array}$ \\
\hline 8. & Flattering & 2 & 6.9 & $\begin{array}{l}\text { (1) Wife and Pancake, } \\
\text { (2) Buying Oil }\end{array}$ \\
\hline & Total & 29 & 100 & \\
\hline
\end{tabular}


Nasrdin Avanti uses eight problem-solving strategies, as illustrated in Table 1. Furthermore, these folktales of Nasrdin Avanti fulfil different functions in their cultural and social contexts as discussed along the way.

Of the 29 stories, the most frequent strategy is talking nonsense (six stories), followed by feigning ignorance (four), satirizing (four), and using the same reasons as the antagonists (four). Next, playing on words, staying one jump ahead and taking advantage of the situation are employed equally frequently (three). The least frequent strategy is flattering (two).

\section{5}

\section{Discussion}

In breaking conventional patterns of thinking and being, Nasrdin Avanti uses eight problem-solving strategies. These folktales also serve a variety of functions for those who are part of this culture as discussed below:

\subsection{Talking Nonsense}

Talking nonsense is the most frequent strategy that the trickster hero employs in solving problems or facing situations. As a product of human imagination, this strategy creates impossible situations and sometimes helps fill gaps in scientific knowledge for people in this culture. One of the stories in which Nasrdin Avanti employs this strategy is Im Wrong. In it, he sees some horsemen passing by a graveyard. Suspecting that they might be up to no good, he hides in a freshly-dug grave. As a horseman sees him moving down there, he addresses Avanti:

"Who are you?"

Avanti put his head out of the grave and answered:

"Oh, I'm one of the dead men buried in this graveyard."

"And what does a dead man want to be up for at this time of night?"

"Just to get some fresh air."

"Does a dead man need fresh air too?"

"Ah yes, yes ... You're right, and I'm wrong!" So, saying Avanti crept back into the grave again.

“The Frog Rider" 1980: 111-112

The trickster hero acts as a corpse who wants to get some fresh air in the same way that human beings do. Although his joke breaks the rule of nature, Avanti lets the horsemen know they are being watched. This inhibits them from doing 
whatever it is - presumably something bad - that they are there for. It would have been of no use for him to have told the horsemen that he was a not corpse but a living person.

In addition to the previous tale, Ask the Cow Herself is another story in which Avanti talks nonsense. In this story, Avanti buys a cow in the market and makes his way home with it. On the way, several passers-by annoy Avanti by asking him about the cow. Finally, when two more men ask him the same questions, he points to the cow and says: "Kind gentlemen, why should you all bother me so much? If you want to hear an answer, why don't you ask the cow herself?" Avanti talks nonsense because he wants to be asked no more questions. Obviously, everybody knows the cow cannot speak for herself.

As well as the stories above, Fish Will Climb a Tree and All Directions are two more stories in which the trickster hero talks nonsense. In Fish Will Climb a Tree, Nasrdin Avanti is asked: "If water is set on fire, what'll happen to all the fish in it?" And he answers: "They'll climb up a tree of course!" In the same way, in All Directions, he is asked: "Why do people go hither and thither in all directions as soon as the day dawns." And he answers: "Isn't it quite clear? If all the people went in the same direction, wouldn't the earth list on that side and turn over."

Apart from these four stories, this very strategy is also presented in The Moon and The Sun or the Moon. In these stories, Avanti is asked questions over which it would be useless to ponder. His answers provide people with new perspectives beyond the realms of possibility. The antagonists whom Nasrdin Avanti tricks by using this strategy are horsemen-presumably poor onesand villagers. This suggests that the trickster hero may not want to make these people lose face by criticizing them for committing illegal acts or causing a nuisance as in Im Wrong and Ask the Cow Herself respectively. Also, the hero does not criticize the antagonists for their nonsensical questions as in Fish Will Climb a Tree, All Directions, The Moon and The Sun or the Moon. It would imply that the trickster hero understands that these people would want to hear witty replies or be provided with entertainment. Therefore, these folktales are meant to evoke laughter, giving people an escape from the greyness of reality.

\subsection{Feigning Ignorance}

Another strategy employed is feigning ignorance. The main character sometimes plays pranks on anti-social or villainous characters for a moral reason. Although he fully understands the situations, he pretends to be foolish. How he stops a greedy wedding guest in The Thirsty Pouch is a good example, as illustrated below: 
One day Avanti attended a wedding. One of the guests not only ate a lot of the sweetmeats offered, but stuffed his pouch with them. When Avanti saw what he was doing, he picked up a tea pot and quietly, from behind, poured some tea into the guest's pouch. When the guest discovered what Avanti had done, he was not at all abashed, but reproached Avanti.

"What's my pouch got to do with you that you come and pour tea into it?" [sic]

"I meant no harm," was Avanti's defence. "When I saw how many sweets your pouch had tucked away, I was afraid it would get thirsty. That's why I gave it a drink."

“The Frog Rider" 1980: 122

Feigning ignorance, Avanti attacks the pouch of this anti-social person, instead of directly criticizing him for his greediness.

Another example is given in Selling a Cow. In this story, his wife wants to sell their cow, which is bad-tempered and barren. At the market, Avanti says: "You may not be able to get any milk from this cow, but she's quite capable of goring you!" As a result, nobody wants to buy the cow. A cattle-dealer who is amused by Avanti's apparent naivety says to him he will sell the cow for Avanti. The dealer shouts: "Look at this cow—how gentle she is! And not only that—she'll give you fifteen bowls of milk every day. You won't be sorry to have bought her!" Hearing this, Avanti takes the cow's tether out of the cattle-dealer's hand and says: "If she is gentler than a lamb and gives fifteen bowls of milk every day, why should I sell her?" This trickster hero pretends not to know that the cattle dealer's advertising spiel is untrue. Feigning ignorance, Avanti appears to take his words literally. Thus, it can be assumed that it is only his wife who wants to sell the cow whereas Avanti himself wants to keep it.

These two stories, The Thirsty Pouch and Selling a Cow, portray how to deal with a greedy person and a liar. By feigning ignorance, the trickster hero promotes social stability. He himself stops these offensive characters from taking advantage of other people such as generous hosts or would-be buyers in respective stories. Therefore, these folktales educate people to be considerate and honest, which is essential for social harmony.

Also, Nasrdin Avanti feigns ignorance in His Tail in the Bag and Expiation, but this strategy does others more harm than good. In the former story, he cuts a donkey's tail, which gets dirty. He is afraid that the donkey with a dirty tail will not be saleable. When a potential customer sees the creature with no tail, he says: "A nice donkey, but what a pity, he has no tail!" Then Nasrdin Avanti answers: "If you've taken a fancy to this donkey, tell me how much you'd like to pay for him. His tail is in the bag here." In the latter story, the trickster hero 
expresses his disbelief in the omniscience of gods. The story is recounted as follows. Once, Nasrdin Avanti finds a stray sheep. He takes it home, kills it, and eats it. It happens that someone who has heard of this asks him: "What will you say to our Lord about this sin [...] on Judgment Day?" Then the trickster hero replies: "I shall say that I haven't eaten the sheep." Then that person asks him what if the sheep appears to give witness. Nasrdin Avanti says to him: "If the sheep appears, that'll be just fine! I'll take it back to its owner and settle the whole business." The trickster hero in these two stories feigns ignorance at the expense of others. In making people laugh, these humorous tales release them from social and moral concerns.

\subsection{Satirizing}

Nasrdin Avanti sometimes deals with unfavourable situations by using satire. His satire criticizes folly and vice in a humorous way. Satire, according to Hodgart (2010), is a combination of aggressive denunciation and some aesthetic features. According to George Orwell, a famous writer and essayist, there is a long history of satire where the follies of those in power are exposed. There is also humour which makes an ironic comment about human weaknesses in general. The aim of a joke is not to degrade the human being but to remind him that he is already degraded (cited in Ross 1998). Whether its prevailing tone is comic or serious, the moral purpose of the satirist is to mend the world (Ogborn and Buckroyd 2013:11). In this series, there are four stories in which the trickster hero satirizes his opponents.

In the story Hiding from the Thief, Avanti wittingly opposes a theft by means of satire. Needless to say, thieves are people who cause problems not only for the rich but also for a poor man like Avanti. Unlike most people, Avanti satirizes this particular thief, presumably to shame him, as is recounted below:

One day a thief broke into Avanti's house. Avanti saw him and hid in a chest.

The thief ransacked the house without finding anything worth taking. In the end he opened the chest and saw Avanti. "Aha!" he said, "and what are you doing inside the chest?"

"I was ashamed that there was nothing in my house that would appeal to your taste. That's why I hid here," Avanti confessed.

"The Frog Rider" 1980: 112

Wittily satirizing the theft, the trickster hero shows this burglar that he himself is anti-social and stupid, for he has not realised that Avanti is not rich. 
Apart from the above story, At the Barber's shows Nasrdin Avanti satirizing his antagonist. Here is the story:

Avanti went to a barber's to have his head shaved.

The inexperienced barber cut him in several places which he dressed with cotton-wool [sic]. Standing up after the ordeal and looking at himself in the mirror, Avanti exclaims:

"What a gifted pair of hands you have! Now that you've planted cotton on one half of my head, I can go home and plant linseed on the other." So, saying, he went away.

"The Frog Rider" 1980: 120

Avanti voices his dissatisfaction by speaking to the barber in a satirical tone. It is Avanti's way of criticising the barber for his incompetence, which has caused him pain.

Another example of satirizing is found in The Guest and the Honey. In it, Avanti is invited to the place of this friend who is supposed to provide Avanti with hospitality. And Avanti, as a guest, is supposed to be served generously. Avanti eats all the pancakes on offer until none is left to eat with honey. Later, he swallows the honey down to the last drop. It happens that the host admonishes him: "You can't eat honey without pancakes! It'll upset you." Avanti replies: "Only God knows who will be upset in the end. May He pour His Blessing over you...." And then he walks away. This shows Avanti satirizing the host for being stingy. Avanti knows it is his friend who should be upset, not he himself, but he does not say so directly.

Not only does Nasrdin Avanti satirize human characters, but he also satirizes a four-legged creature, like a donkey. In Jump into the Water!, the trickster hero performs a task without any flexibility to adapt to a circumstance. He directs his satire against his donkey who does not know that Avanti acts in good faith to warm him up in the cold weather. The animal is frightened when Avanti lights firewood on its back and it gallops away fast. He shouts after it: "If you're smart enough, you'll jump into the water!" His satirical comment implies that for him, this creature does not understand his good will. The donkey, Avanti's animal companion, may represent a person in an inferior position. As a subordinate, the donkey is supposed to obey his master's instructions. In this respect, this story has a role in maintaining the hierarchical social structure in which subordinates are required to learn obedience, regardless.

In brief, Nasrdin Avanti sometimes satirizes those who have done something bad or unpleasant to him. In the stories of which the antagonists are human beings, such as the thief, the barber, and his friend, Avanti's satirical comments 
remind them that they are already degraded because of their stupidity, incompetence, and stinginess. As for the four-legged creature, representing a subordinate, Avanti reminds it of this status. In this light, these four stories inculcate socially acceptable behaviours and maintain the social hierarchy.

\subsection{Using the Same Reasons as the Antagonists}

Problems can arise from antagonists' false reasoning. In this situation Nasrdin Avanti uses such false reasoning to solve problems. The reader can see how the trickster hero solves problems by playing with the logic of his opponents in the stories The Only Remedy, The Ring, Difficult Questions, and The Price of a Fowl.

In The Only Remedy, Avanti is asked by a neighbour who intends to make fun of him: "Last night, a mouse crept into my stomach while I was sleeping. What shall I do?" Avanti humorously replies: "What you must do at once is to find yourself a live cat and swallow it. That's the only possible remedy for you." In the real world, it is impossible for a mouse to creep into a person's stomach, but it is something that can happen in the world of tales. Likewise, it is impossible for a live cat to be introduced into someone's stomach to catch a mouse there. Cleverly, the trickster hero uses such false reasoning to turn the tables on the neighbour, thus solving the false problem. He does not take his neighbour's words seriously, which would create tensions. Rather, he gives an answer that stirs the imagination in the same way his neighbour asks the question. The trickster hero would be concerned with the face of his neighbour, or he would understand that his neighbour has a sense of fun and expects to hear a witty reply from him. Hence, this folktale not only provides amusement but also validates the culture.

The Ring is another example in which Nasrdin Avanti uses the antagonist's false reasoning to deal with an awkward situation. In this story, one of Avanti's friends - a businessman - comes to say goodbye to him. As he sees Avanti wearing a golden ring, he schemes to get it. He says: "I'll be missing you so much when I am away. Why don't you let me have your ring for the sake of our friendship? Whenever I look at it, I'll then feel like I'm seeing you in the flesh." Avanti, who has no other valuables apart from this ring, replies: "But I too cannot live in peace if I have to miss you for a long time. Be merciful and let me keep the ring! Whenever I look at it, I'll remember how my friend asked me for it." It is clear that Avanti's friend brings in friendship for his own benefit, but Avanti uses the same reason to protect his only asset. This strategy enables him to save his face and protect his only asset. And at the same time, it seems to reinforce the sense of friendship. In this respect, Avanti's answer would suggest his concern about self-face and other-face maintenance for the purposes of maintaining relational harmony and diffusing shame and embarrassment. 
Therefore, this story exemplifies how people in this culture attach great value to building and nurturing relationships. In this respect, this story reinforces morals and values.

Apart from The Only Remedy and The Ring, another story in which Nasrdin Avanti turns the same reason against the antagonists is The Price of a Fowl. In this story, the trickster hero deals with unfair religious people and a tricky businessman. The story is recounted as follows. There is a porter who has fowl for dinner at an inn. When he asks for the bill, he finds that the price of the fowl is several hundred times higher than the ordinary market price. The innkeeper reasons: "If you hadn't eaten that hen, how many eggs could she have laid? And the eggs would have become laying hens again and they would have grown up to lay eggs...." Unfortunately, the Imam agrees with the innkeeper. In this case, Avanti advises the porter to ask the Imam to hold a public trial at which he himself will be a lawyer. On the trial day, the trickster hero comes to the court late. He gives his reason: "I'm going to sow wheat tomorrow, but the wheat seeds weren't roasted yet. Could there be anything more urgent than that [...]?" The Imam and the men of the jury yell: "That's all nonsense. Can roasted wheat seeds grow?" To which Avanti replies: "You are quite right—wheat seeds that are roasted cannot grow. Then, I want to ask you: How can a fowl lay eggs after it's been eaten?" At that, the members of the jury cancel the previous verdict. This is to say that after the antagonists use the false reason to take advantage of the porter, Avanti offers similar false reasoning to win the case against his antagonists. He snatches victory from his antagonists who people find unfair and tricky. In this regard, this folktale reveals the antagonism of people of low standing toward dominance and dominators like the religious people and the rich. Thus, this story serves as a social outlet in its criticism against them.

Moreover, in Difficult Questions, the trickster hero uses the same reason as his antagonist. Nasrdin Avanti in this story deals with foreign tradesmen. He is summoned by the king to answer three questions posed by a trio of tradesmen who came to a certain kingdom, after everyone else in the kingdom has failed. Avanti manages to answer their conundrums. The first tradesman asks: "The earth has a navel. Where is it?" Avanti points with his stick and answers: "Right here, on the piece of ground under my donkey's right front leg." The question put by the second tradesman is "How many stars are there in the sky?" Avanti replies: "Count the hairs on my donkey's back and you'll know the answer." The question asked by the third tradesman is "You see the beard I have-tell me the number of hairs in it!" Avanti answers: "If you tell me how many hairs there are in my donkey's tail, I'll tell you how many hairs there are in your beard." It is obvious that the three tradesmen's questions are unanswerable, but Avanti's equally unanswerable questions stymie them. That is to say, Avanti uses the 
same reasoning to nullify his antagonists' unanswerable questions. The fact is that Avanti, representing his kingdom, defeats these foreign tradesmen and restores the king's honour and the pride of the nation. Thus, this story reflects a culture in which people place a value on community. Moreover, this story, when it is told within the group, contributes to the solidarity of the kingdom.

In sum, Nasrdin Avanti uses the same reason as the antagonists in these four stories to deal with impossible and awkward situations and unanswerable questions, regardless of what the antagonists' purposes are. As for functionalism, these stories provide social and psychological benefits for people in this culture.

\subsection{Playing on Words}

Sometimes, the trickster hero Nasrdin Avanti humorously plays on words. The story A Bargain Made Even provides a good example. This story has an element of ambiguity as recounted below:

One day Avanti went to the market to buy himself a pair of trousers. Having settled the bargain, he was just about to pay for them when he changed his mind. “After all, this pair of trousers I'm wearing isn't quite finished yet," he muttered to himself. Then he turned [sic] to the shop keeper and said: "Better exchange these for a shirt, please!"

The shopkeeper saw nothing wrong in this request and handed him a shirt. Avanti snatched it from the man and walked off without paying for it. The shopkeeper sprang to his feet shouting: "Why aren't you paying for what you've bought?"

"Haven't I given you the trousers whose price we had already settled?" retorted Avanti.

“The Frog Rider" 1980: 113-114

Nasrdin Avanti does not pay for the shirt but he claims that the price of the trousers has already been 'settled.' It is worth mentioning that 'settle' has a double meaning here. In some contexts, 'settle' means to pay, especially money that you owe, ${ }^{3}$ but in others, it means to reach a decision or an agreement about something. ${ }^{4}$ For Avanti, 'settling' the price means paying the price, but for the shopkeeper, it means reaching an agreement. In this case, the trickster hero makes a pun, or a joke exploiting different possible meanings of the word. This strategy makes the shopkeeper come to the realization that the word 'set-

3 Cambridge Dictionary Online (Definition 5). Retrieved June 7, 2016.

4 Cambridge Dictionary Online (Definition 1). Retrieved June 7, 2016. 
tle' has a double meaning. This folktale, when told as fiction, is entertainment, perhaps escapism for people in this culture, who are bound to uphold the principles of logic and live in the greyness of reality. It would free its audience, if only temporarily, from personal and social concerns.

Another example in which Avanti plays on words is found in The Baggage of Two Asses. He says things that are inappropriate and culturally forbidden. Resisting being put upon, he criticizes the king. The story is told as follows:

King Tomur and his favourite courtier went hunting and took Avanti along. On the way, when Tomur and the courtier began to feel hot, they took off their coats and let Avanti carry them on his back. When Tomur saw that Avanti was sweating like anything, he mocked him.

"Avanti you're carrying as much as an ass!"

But Avanti was quick with a retort: "No, my lord, I'm carrying the baggage of the two asses."

"The Frog Rider" 1980: 121

Whereas the king uses a simile to compare Avanti to an ass, Avanti uses a metaphor to compare the king and his favourite to two asses. He just changes a few words. 'As an ass' is changed to 'of the two asses.' Avanti as a fictional character shows refusal to be put-upon in a way that cannot be done by a commoner to a king, in the real world. In other words, Avanti criticizes the king, implying that he and his courtier are stupid when they exploit Avanti by having him carry their belongings. Thus, this humorous folktale serves as a safety valve, responding critically to the privilege of the community leader and social injustice.

Good Advice also features the trickster hero paying the antagonist back for his deceit by playing on words. In this story, a man claims that he has three pieces of good advice to give anyone who is carrying a crate full of bowls and cups. With the intention of deceiving Nasrdin Avanti, the antagonist offers his three pieces of advice in exchange for his work. Avanti thinks that a thing like money can be obtained at any time, but good advice is difficult to get, so he agrees to carry the crate on these terms. The first piece of advice is, "Don't believe anybody who tells you that it is better to go hungry than to eat your fill." The second piece of advice is, "Don't believe anybody who tells you that it is better to go on foot than to ride on horseback." And the last piece of advice is "Don't believe anyone who tells you that there are porters even more foolish than you." These three pieces of advice begin with 'Don't believe.' The first two phrases are just common sense which everyone knows. However, the last is an insult to Avanti's intelligence. Apparently, he then lets go of the rope in his hand and says: "And don't believe anyone either who tells you that the bowls 
and cups in the crate aren't broken," Avanti thus plays on the words 'don't believe' as in the antagonist's three pieces of advice. This implies that he is not outwitted and he is seeking pay-back. Consequently, this folktale serves as an item providing psychological release for a vengeful individual.

In short, these three stories show how the trickster hero plays on words. By employing this problem-solving strategy, the trickster hero teases the shopkeeper as in A Bargain Made Even. Moreover, he seeks revenge on those from of a higher status, such as the king and the employer as in The Baggage of Two Asses and Good Advice respectively. These humorous stories help free people from social and moral restraints.

\subsection{Staying One Jump Ahead}

To deal with his opponents, the trickster hero Nasrdin Avanti sometimes keeps himself one jump ahead. In a given situation, he sees a problem where others have not yet seen it. He, in turn, studies the resulting situation and comes to a conclusion that other people would not have arrived at. The stories in which he uses this strategy are It's No Good to Be Inside, Write for Me, and Path Along the Tree-tops.

In It's No Good to Be Inside, the trickster hero deals with the socially-sensitive subject of death. In it, Avanti is asked: "When you attend a funeral, is it better to walk ahead of the coffin or behind the coffin?" Avanti answers: "Either will do, as long as you aren't inside." Not choosing either of the options offered, the trickster hero seems not to directly answer the question. However, he has a good reason beyond the interlocutor's expectation, but it is left unexplained. Avanti's answer is just right when the interlocutor understands his point that to be alive is far better than to be dead and lie in a coffin, and one should not be bothered with such a question. And this answer makes the questioner pay less attention to the unimportant matter of the funerary rite and realize the importance of living his life in this earthly world.

Write for $\mathrm{Me}$ is another example depicting how the trickster hero decides to respond to a request for help. Through the strategy of staying one jump ahead, he manages to do his best for himself and for others. In it, a friend of Avanti asks him to write a letter, and Avanti gives him an answer which sounds uncooperative. Here is the story:

One of Avanti's friends came to him saying: "I have a brother living in the capital. Would you mind writing him a letter for me?"

"But I don't think I have time to go to the city!" said Avanti.

"I'm not asking you to go to the city," the friend explained. "I only asked if you would be kind enough to write him a letter." 
"I understood you perfectly the first time," Avanti replied. "But nobody can decipher my handwriting except myself. So if I'm not there to read it to him, it's no use writing. That's why I say I am not going to the capital."

"The Frog Rider" 1980: 117-118

His answer, "But I don't have time to go to the city," initially seems irrelevant to the request. In fact, Avanti stays one jump ahead in this conversation. In responding, he explains to his friend that if he writes a letter for him, he will later be asked to go to the city to read his illegible handwriting. But instead of refusing directly by saying 'no', he implies that his friend's brother would gain no benefit by receiving a letter he could not read. Moreover, employment of this strategy allows Avanti to stand his ground by being attentive to his priorities.

Apart from the previous two stories, Along the Tree-tops is the other story in which the trickster hero stays one jump ahead. However, it is unlike the other two stories in that in this case, this problem-solving strategy is revealed not only from his words but also in his action. He gives the interlocutors a clear reason at the same time that he prepares himself for what will come. In this story, some children ask him to get birds' eggs out of a tree for them. But he knows that the children will steal his boots if he leaves them on the ground while climbing the tree, so he ties them to his belt before he starts climbing. When they say: "We'll take care of your boots for you, Avanti," Avanti replies: "No, thank you! I'm a busy man. And as soon as I've got the eggs for you, I will make my way home along the tree-tops." Staying one jump head, Avanti averts the danger of the children stealing his boots. Extending his hospitality, the trickster hero provides assistance for those in need of it. By resorting to this problem-solving strategy, he can avoid becoming a victim of the antagonists' trick. In this way, the trickster hero reminds us that the world is not a tragedy, but a comedy in which we can behave with compassion for others as long as we know how to deal with the fundamentals of human nature.

In brief, these three stories depict how Avanti stays one jump ahead in the process of providing advice on the right way to lead our lives. In particular, the lesson in It's No Good to Be Inside suggests that we ponder the precious and wonderful things about earthly human life. Similarly, in Write for Me, the trickster hero gives us advice on pursuing our agendas, while in Path Along the Tree-tops he provides a lively example of moral teaching. In such ways, these folktales educate us by means of example.

\section{$5 \cdot 7$} Taking Advantage of the Situation

Nasrdin Avanti sometimes provides examples of taking advantage of a situation when he solves a problem. In spite of being put into an unfavourable 
position, he manages to change it to his advantage. Regardless of the initial advantages of the thieves, the king, and his creditor, Avanti manages to emerge the victor in the situations they involve him in.

For example, in Avanti Moves House, he confronts an anti-social group by taking advantage of the situation. In it, a gang of thieves steal furniture and other belongings from his house. Not opposing them, Avanti just follows, carrying some small articles in his hands. After one of the thieves greets him amicably, Avanti tells them: "I've been wanting to move for a long time but couldn't afford a cart for my things. It's very kind of you to help me like this." This shows Avanti turning a bad situation into one that is favourable, turning the tables on the would-be villains.

What Does the Owl Say? is another example of Avanti turning a situation to his own advantage. In it, the trickster hero directs criticism against kingship. After bragging that he knows the language of the birds, Avanti is tested by the king. When he sees a wall in ruins and an owl hooting above it, he asks Avanti to translate what the owl is saying. Avanti tells him: "It says that if the king keeps on riding roughshod over the people, his kingdom will soon crumble, just like the owl's nest did." Seeing the king treating his people with brutal injustice, he warns him to change his ways or face the consequences, doing so by pretending to know the language of birds.

The Pot Bears a Son is a story in which Avanti solves a problem once again by turning a negative situation to one in his own favour. In this story, Avanti borrows a big iron pot from a rich but stingy man who lends the pot intending to claim interest for its use. When Avanti brings a small iron pot to his creditor, saying it is the big pot's son, the rich man accepts it and asks Avanti to take good care of the iron pot, pretending that the unreturned big pot is like a living thing in that it can produce offspring. Later, Avanti tells this creditor that the pot has died and he has buried it in the blacksmith's forge. This leads to a fight. It draws a big crowd, which causes the rich man to lose face. This is to say, the trickster hero has wittily once again reversed the negative situation in which he has found himself.

In short, these three stories show that Avanti never loses control of the situations he gets into. By taking advantage of the situation, the trickster hero can deal with the anti-social thieves, the corrupt king, and the stingy rich man, as seen in Avanti Moves House, What Does the Owl Say? and The Pot Bears a Son respectively. Thus, these folktales offer an escape into an alternative world in which people can feel satisfied with triumphs over such individuals. 


\subsection{Flattering}

Flattering is the least frequent strategy that Avanti employs. Nevertheless, the trickster hero sometimes flatters people, his wife in particular, aiming to keep her happy, while at the same time serving his own ends. In this series, there are two stories joking about the relationships between men and women. One of the stories is Wife and Pancake, recounted as follows:

Avanti and his wife sat on the floor chatting. Feeling hungry, Avanti asked her: "Don't you have any pancakes around?"

"Can't you be satisfied just sitting here and looking at your beautiful wife?"

"Of course I can," said Avanti. "But if I could have a pancake to eat while looking at your beautiful face, that would be even better."

“The Frog Rider" 1980: 120

Avanti's flattery indirectly persuades his wife to cook a pancake for him. His words of praise serve to provide what it is he wants.

The other story in which the trickster hero employs this strategy is Buying Oil. In it, he has been away from home for a long time and his wife speaks to him angrily on this account. Avanti makes a low bow and asks for Heaven's blessings. He smiles at his wife and says: "My beloved little skylark, aren't I back now?" At this, his wife's anger disappears, and then she flies into his open arms, like a real skylark. His term of endearment, "My beloved little skylark," comparing her to the bird noted for the beauty of its song, mollifies her.

These two stories reinforce the power of women's authority in the domestic setting. Avanti flatters the wife who controls everything in her domain by referring to her attractive appearance as well as her cooking and singing abilities. The issue in these two stories is not Avanti's loss of status. It is more about the success of Avanti's problem-solving strategy in persuading his wife to do her duties, which includes maintaining her husband's well-being and welcoming her husband home. Therefore, these two stories can be viewed as a form of cultural reinforcement that naturalizes the gender roles. In this way, these folktales maintain conformity to dominant patterns of behaviour.

In the world of tales, anything can happen. Using his native wittiness, intelligence, and originality, Nasrdin Avanti, the trickster hero, manages to solve problems, overcome difficulties, and answer questions. Despite having no 
magical abilities, he can confront antagonists and succeed in every situation by employing one or another of his eight problem-solving strategies, namely talking nonsense, feigning ignorance, satirizing, using the same reasons as the antagonists, playing on words, staying one jump ahead, taking advantage of the situation, and flattering. These strategies help him achieve his ends, make the antagonists lose face, stop them from bothering him and taking advantage of him, and provide others with new perspectives. Generally, these folktales of Nasrdin Avanti, in providing social and psychological benefits, serve paradoxical functions. On the one hand, they help retain social values and inculcate moral lessons. On the other, providing amusement, they allow people to escape from the harsh realities of their day-to-day physical and cultural environment. Although most of the stories appear as jokes, each of them invites deep thought. In this way, the trickster hero Nasrdin Avanti can be regarded as a typical cultural hero. While idealising and upholding the principles of the Uyghur people, his stories travel far beyond their locus of origin and become memorably thought-provoking and humorous folktales for everyone.

\section{References}

Alexander, Tamar. 2003. Introduction. In Folktales of Joha: Jewish Trickster, collected and edited by David Herman, pp. $5^{-16}$. Philadelphia:The Jewish Publication Society.

Bascom, William R. 1954. Four Functions of Folklore. The Journal of American Folklore $67.333-349$.

Bovingdon, Gardner. 2010. The Uyghurs: Strangers in Their Own Land. New York: Columbia University Press.

Bronner, Simon J. 2017. Folklore: The Basics. Kindle edition. London: Routledge.

Brym, Robert J. and John Lie. 2005. Sociology: Your Compassion for a New World. and edition. Belmont: Wadsworth.

Clarke, Kenneth W. and Mary W. Clarke. 1963. Introducing Folklore. New York: Holt, Rinehart and Winston.

Dundes, Alan. 1965. The Study of Folklore. New Jersey: Prentice-Hall.

Elcot, Sam. 2003. Immortal Tales of Mulla Nasrudin. Kindle edition.

Gramsci, Antonio. 1971. Selections from the Prison Notebooks. Translated and edited by Quintin Hoare and Geoffrey Nowell Smith. New York: International Publishers.

Hansen, George P. 2001. The Trickster and the Paranormal. Bloomington: Xlibris.

Hodgart, Matthew. 2010. Satire: Origins and Principles. London: Routledge.

McNeill, Lynne S. 2013. Folklore Rules: A Fun, Quick, and Useful Introduction to the Field of Academic Folklore Studies. Logan: Utah State University Press.

Merriam-Webster's Encyclopedia of Literature. 1995. Springfield, MA: Merriam Webster. 
Ogborn, Jane. and Peter Buckroyd. 2013. Satire. Cambridge: Cambridge University Press.

Ross, Alison. 1998. The Language of Humour. London: Routledge.

Shelton, Michael. 2014. Once There Was, Twice There Wasn't: Fifty Turkish Folktales of Nasreddin Hodja. Boston: Hey Nonny Nonny Press.

Thompson, Stith. 1949. Folktale. In Standard Dictionary of Folklore, Mythology and Legend, edited by Maria Leach and Jerome Fried. pp. 408-415. New York: Funk and Wagnalls.

Thompson, Stith. 1977. The Folktale. Berkley: University of California Press.

Zhang, Suchu. 1980. The Frog Rider_Folk Tales from China (First Series). Beijing: Foreign Language Press. 